\title{
Applying Q-methodology to study customer satisfaction with quality of community pharmacy services in Vietnam
}

\author{
Van De Tran ${ }^{1,2 \star}$, Valeria Valeryevna Dorofeeva ${ }^{1}$ \\ ${ }^{1}$ Department of Pharmaceutical Management and Economics, Peoples' Friendship University of Russia, Moscow 117198, \\ Russia, ${ }^{2}$ Faculty of Medicine, Can Tho University of Medicine and Pharmacy, Can Tho 902490, Vietnam
}

*For correspondence: Email: vandepro@gmail.com; Tel: +79-851927647

\begin{abstract}
Purpose: To determine the pattern of customers' viewpoints regarding their satisfaction with the quality of services of community pharmacies in Vietnam.

Methods: Q-methodology was applied to identify distinct patterns of subjective perception on community pharmacy services. A Q-sample of 40 statements was developed following a review of the literature. The study recruited 144 customers from 40 pharmacies in four Vietnamese cities. They were required to sort 40 statements into a quasi-normal distribution grid according to their degree of satisfaction with the quality of community pharmacy services. Data collected were analyzed using $P Q$ Method software version 2.35.

Results: This study identified three factors indicating three patterns of perspectives concerning customer satisfaction on the quality of community pharmacy services: Factor 1: accessibility of the community pharmacy; Factor 2: availability of medication consultations; Factor 3: accessibility of medicines.

Conclusion: There are three main patterns of viewpoints concerning customer satisfaction with community pharmacy services in Vietnam. The findings should contribute to improving the understanding of pharmaceutical policymakers and pharmacy staff regarding customer satisfaction with current pharmaceutical services.
\end{abstract}

Keywords: Community pharmacy, Customer satisfaction, Q-methodology, Pharmaceutical policymakers, Pharmacy staff

This is an Open Access article that uses a funding model which does not charge readers or their institutions for access and distributed under the terms of the Creative Commons Attribution License (http://creativecommons.org/licenses/by/4.0) and the Budapest Open Access Initiative (http://www.budapestopenaccessinitiative.org/read), which permit unrestricted use, distribution, and reproduction in any medium, provided the original work is properly credited.

Tropical Journal of Pharmaceutical Research is indexed by Science Citation Index (SciSearch), Scopus, International Pharmaceutical Abstract, Chemical Abstracts, Embase, Index Copernicus, EBSCO, African Index Medicus, JournalSeek, Journal Citation Reports/Science Edition, Directory of Open Access Journals (DOAJ), African Journal Online, Bioline International, Open-J-Gate and Pharmacy Abstracts

\section{INTRODUCTION}

The community pharmacy is an integral component of the primary health care system that improves and enhances the public health of the community [1]. Traditionally, community pharmacy is viewed as a retail channel that performs the primary function of distributing quality-assured medicines to patients [2]. However, in recent years, the role of the community pharmacy has shifted to patientoriented care in place of medicine-centered services [3], which contributes to ensuring rational medication use and monitoring chronic patients [4,5].

Today, the community pharmacy is the most 
frequent destination of patients who face healthrelated problems [1]. The convenience of access and the availability and cost-effectiveness of medicines are some of the main reasons given by customers who seek pharmaceutical care from pharmacies $[6,7]$. In developing countries, community pharmacies are considered a replacement of other healthcare services [8]. Customers often choose community pharmacies for self-medication [9]. In Vietnam, the majority of patients prefer to go to community pharmacies for medicine counseling, getting prescriptions, or self-medication [10,11], resulting in pharmacies becoming the most used services, accounting for two-thirds of all healthcare services [11].

With the goal of improving the effectiveness of pharmaceutical practice at pharmacies in Vietnam, in 2007 the Vietnam Ministry of Health promulgated the "Good pharmacy practice" standard, which specified the responsibilities of pharmacists from providing quality medicine to counseling and monitoring the proper use of medicine [11]. However, the supply of highquality and effective pharmaceutical services is a challenge for Vietnam. According to the study conducted by Smith in 2009, pharmacies in developing countries including Vietnam still play a limited role in the provision of health services [12].

Greater knowledge and understanding of the pharmacy customers' perceptions can improve and enhance the timeliness and quality of community pharmacy services in the context of current practice in Vietnam. In addition, previous studies in Vietnam investigating customer satisfaction on community pharmacy services were mainly conducted in a particular region; there is limited research that takes into consideration the whole country. Therefore, the purpose of this research was to explore the customers' perspectives on the quality of pharmaceutical services provided by community pharmacies in Vietnam.

\section{METHODS}

Q-methodology, also known as by-person factor analysis [13], is a strong and unique combination of both qualitative and quantitative research methods [14], with the aim of arriving at a deep understanding of the individual's subjective viewpoints, attitudes, beliefs, and opinions regarding a study issue [15]. The use of Qmethodology has significantly increased in the fields of social sciences and humanities [16] but has not been widely applied in the field of pharmacy, especially to studies on customer satisfaction. In this research, Q-methodology was applied to explore different types of customer perspectives regarding the quality of pharmaceutical services. The procedure for the study using Q-methodology comprised the following five main steps: (1) development of a concourse based on the research topic; (2) definition of Q-sample; (3) recruitment of a P-set of respondents; (4) completion of the Q-sort; and (5) data analysis and factor interpretation.

\section{Concourse}

In Q-methodology, a concourse is a very large set of statements, also known as "universe of viewpoints" [17], comprising all possible aspects that relate to the study topic [18]. The method that is usually used to develop the concourse includes a review of literature, interviews, and focus groups in order to ensure that a representative set of diverse ideas, beliefs, attitudes, and opinions on the issue of interest is obtained [19]. In this study, a concourse of more than 120 statements was developed by nonsystematically reviewing 30 articles related to the understanding of customer perspectives on community pharmacies.

\section{Q-sample}

Once the concourse has been determined, the next step is to develop a $\mathrm{Q}$-sample with a fewer number of statements that still represent the original concourse. The ideal Q-sample recommended usually comprises 40-80 statements [20]. Moreover, the size of the Qsample is usually approximately one-third that of the concourse [21]. In the current study, a structured sampling method was used by selecting several representative and appropriate statements from the concourse and classifying them into the following four categories: (1) community pharmacy, (2) medicine, (3) pharmacist's knowledge, skills, attitude, and (4) pharmacist's behavior. Next, two experts from the pharmacy field evaluated and corrected the statements to make the language simple and clear for the participants. This process resulted in a final Q-sample comprising 40 statements.

\section{P-set}

The P-set is defined as the group of respondents completing the Q-sort. Q-methodology does not require too many participants. Between 40 and 60 participants are considered adequate enough for most Q-methodology studies [20]. Furthermore, participants were not randomly selected from a particular population to be representative of that population [22]; in contrast, participants with a variety of potentially different 
viewpoints were intentionally selected in accordance with the goals of the study [16]. In this study, pharmacy customers of both sexes, different age groups, and diverse educational and geographic backgrounds were mainly recruited from 40 community pharmacies in four Vietnamese cities: Hanoi, Da Nang, Ho Chi Minh, and Can Tho. In each city, five community pharmacies located in the city center and five located on the outskirts of the city were selected for the study, which was conducted from July 10th to September 10th, 2017.

\section{Q-sort}

To prepare for the Q-sorting process, each statement from the Q-sample was randomly numbered from 1 to 40 and each statement and number was then imprinted on to small cards. Participants were asked to read and sort 40 cards into the forced quasi-normal distribution grid (shown in Fig. 1) according to their degree of satisfaction or dissatisfaction with the quality of pharmaceutical services of the community pharmacy. This resulted in each participant creating a Q-sort that reflected their perspective on the research topic. A detailed guide on the steps to perform the sorting can be found in Watts and Stenner (2012) [13].

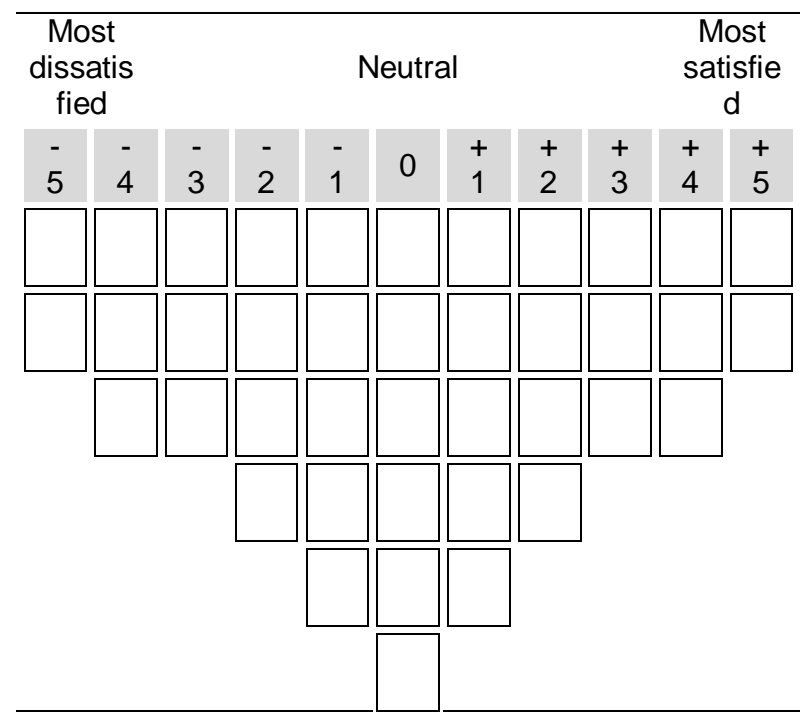

Figure 1: Q-distribution grid

\section{Data analysis and interpretation}

All Q-sorts data were entered and analyzed using PQMethod software version 2.35 [23]. Factors, known as the patterns of distinct viewpoints, were extracted using centroid factor analysis and then rotated using the varimax method. The following four evaluation methods were conducted to identify the optimal amount of factors to retain: (1) Kaiser-Guttman or eigenvalues greater than one criterion [24,25]; (2) factors with two or more significant factor loadings [17]; (3) scree test [26]; and (4) parallel analysis [27]. The scree test and parallel analysis were based on eigenvalues that were computed using principal component analysis as suggested by Q-methodology researchers [13]. Parallel analysis based on 1,000 random datasets' generation of the original data using IBM SPSS version 22.0 syntax was conducted as per the guidance provided by O'Connor (2000) [28]. In this study, factor loading was considered significant at $p<0.01$ on a factor if its absolute value was greater than 0.41 , based on applying the calculation formula as follows: $2.58 / \sqrt{n}$, where $\mathrm{n}$ is the number of statements in the $\mathrm{Q}$ sample [17].

The process of factor interpretation used the following information: (1) statements with the highest or lowest rank, (2) useful higher or lower ranked statements in the focus factor rather than in other factors [13] and (3) distinguishing statements. Distinguishing statements of a factor are statements for which there are statistically significant differences between the score on that factor and any other factor [29].

\section{RESULTS}

This study included 150 participants, six of whom did not complete the Q-sort; therefore, $144 \mathrm{Q}$ sorts by participants were included in the data analysis. The demographic information of 144 participants indicated that more than half of the respondents were female (51.4\%); most were aged between 18 and 30 years (59.7\%) and had received high school education (43.8\%).

Results of factor extraction showed that 33 factors with eigenvalues above 1.0 satisfied the Kaiser-Guttman criterion. Four factors contained two or more significant factor loadings. The scree plot showed that the inflection point was in the position of the fourth factor (see Fig. 2); consequently, the three factors located to the left of the inflection point were considered appropriate. Parallel analysis, seen in Fig. 2, recommended retaining the three factors because their actual eigenvalue was higher than the 95th percentile eigenvalue from 1000 random datasets. Based on the review of these evaluation methods and the theoretical significance of the extracted factors, the threefactor solution was considered most suitable for the present study data. 


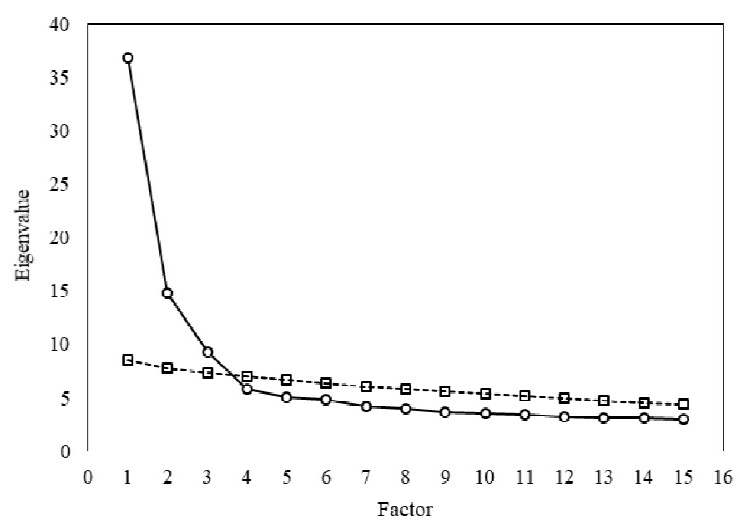

Figure 2: Screen plot and parallel analysis. Key: $\circ=$ Actual Eigen value; $\square=95^{\text {th }}$ percentile Eigen value

As a result of the rotation of the three-factor solution, 104 participants loaded with statistical significance on one of three factors, which accounted for $41 \%$ of the study's total variance. Besides, 20 participants did not load significantly on any one factor. The remaining 20 participants loaded with statistical significance on more than one factor, which is known as confounded sorts.

By using by-person factor analysis, this study identified three factors representing three different patterns of viewpoints concerning customer satisfaction on Vietnamese community pharmacy services: Factor 1-accessibility of the community pharmacy; Factor 2-availability of medication consultations; Factor 3-accessibility of medicines. Detailed information on the characteristics of each factor is given in Table 1 and 2.

\section{Factor 1: Accessibility of the community pharmacy}

Factor 1 had eigenvalues of 24.65, which accounted for $17 \%$ of the study's total variance. This factor had 48 participants who significantly loaded on it. Customers sharing this viewpoint expressed high satisfaction with the convenience of the geographic location, as presented in statement number of 20 at rank position of +5 , abbreviated as $(\# 20:+5)$ on factor 1 (see Figure $3)$. The opening times of the pharmacies $(\# 8:+4)$ and their clean and well-lit working area environment $(\# 27$ : +3$)$ were highly appreciated. Besides, customers appreciated the ability to easily access pharmacies in case of emergency $(\# 25:$ +4) without prior appointment $(\# 14:+5)$. However, they were not satisfied with the comfort of the waiting area and the number of seats (\#11: $-4)$.

Table 1: Statements and their corresponding rank values for three factors

\begin{tabular}{|c|c|c|c|c|}
\hline \multirow{2}{*}{ S/no. } & \multirow{2}{*}{ Statement } & \multicolumn{3}{|c|}{ Factor } \\
\hline & & 1 & 2 & 3 \\
\hline 1 & The pharmacist has high professional knowledge & $-1^{* \pi}$ & $+2^{n \pi}$ & $-1^{\pi \times \pi}$ \\
\hline 2 & The labels of the medicines I get are clear and easy to read & $+1^{\star \pi}$ & $+2^{\approx \pi}$ & $+5^{* \pi}$ \\
\hline 3 & The pharmacist provides easy-to-understand information & +2 & 0 & 0 \\
\hline 4 & The pharmacy always offers medicines at an affordable price & -3 & -3 & +2 \\
\hline 5 & Appearance of the pharmacy is professional and aesthetic & +1 & -2 & +1 \\
\hline 6 & I get advice about how to store medications at home from the pharmacist & $-3^{x \times}$ & $0^{\pi \times}$ & $-5^{\pi \pi}$ \\
\hline 7 & The pharmacist is willing to answer all of my questions & $+2^{\pi x}$ & $+3^{\pi \times}$ & $0^{\pi \pi}$ \\
\hline 8 & Opening hours of the pharmacy are convenient for me & +4 & $-2^{\prime \prime}$ & $+1^{n}$ \\
\hline 9 & I trust the quality of the medicines purchased at the pharmacy & $-1^{\prime}$ & 0 & $+3^{n-}$ \\
\hline 10 & $\begin{array}{l}\text { To prevent mistakes, the pharmacist provides information on medication use } \\
\text { in writing }\end{array}$ & $0^{* *}$ & $+4^{\star *}$ & $-2^{* *}$ \\
\hline 11 & The pharmacy has a comfortable waiting area and a sufficient number of seats & -4 & -4 & $-2^{\pi \pi}$ \\
\hline 12 & $\begin{array}{l}\text { I trust the pharmacist; he honors the confidentiality of information regarding } \\
\text { me and my purchases }\end{array}$ & $-2^{* *}$ & -1 & -1 \\
\hline 13 & After consultations, I am well aware of the rules for taking medicines & +2 & +2 & 0 \\
\hline 14 & $\begin{array}{l}\text { Pharmacy services are easily accessible and no prior appointment is } \\
\text { necessary before a visit }\end{array}$ & $+5^{* *}$ & $-3^{* *}$ & $+4^{* \star}$ \\
\hline 15 & Information on medicine prices is clearly visible & $-5^{\times \pi}$ & $-2^{\pi \times}$ & $+4 \times$ \\
\hline 16 & I get the required amount of necessary medicines & +3 & 0 & $+55^{n}$ \\
\hline 17 & $\begin{array}{l}\text { The pharmacy does not provide for private counseling areas; other customers } \\
\text { can overhear conversations or see the medicines }\end{array}$ & $+1^{\star \star}$ & $-4^{\star *}$ & $-4^{* \star}$ \\
\hline 18 & $\begin{array}{l}\text { If I have health problems, I will go to the pharmacy. After consulting a } \\
\text { pharmacist, I feel better }\end{array}$ & $0^{* *}$ & $-2^{* *}$ & $-2^{* *}$ \\
\hline 19 & $\begin{array}{l}\text { The pharmacist asks me questions related to the disease to ensure that my } \\
\text { medicine use is reasonable }\end{array}$ & $+3^{* *}$ & $+1^{\star *}$ & $-1^{* \star}$ \\
\hline 20 & $\begin{array}{l}\text { The pharmacy is located in a convenient location, close to my home or } \\
\text { workplace }\end{array}$ & $+5^{* *}$ & $0^{* *}$ & $+3^{* *}$ \\
\hline
\end{tabular}

${ }^{*}$ Distinguishing statement with significance of $p<0.05 ;{ }^{* \star}$ Distinguishing statement with significance of $p<0.01$. 
Table 2: Statements and their corresponding rank values for three factors (contd)

\begin{tabular}{|c|c|c|c|c|}
\hline \multirow{2}{*}{ S/no. } & \multirow{2}{*}{ Statement } & \multicolumn{3}{|c|}{ Factor } \\
\hline & & 1 & 2 & 3 \\
\hline 21 & The pharmacist is a courteous, friendly, and helpful person & 0 & $+2^{\pi x}$ & 0 \\
\hline 22 & $\begin{array}{l}\text { The pharmacist indicates how to take medicines and provides advice on their } \\
\text { frequency of use }\end{array}$ & $+4^{* *}$ & $+5^{* *}$ & $+3^{* *}$ \\
\hline 23 & The pharmacist gives advice on maintaining my health and a healthy lifestyle & -4 & $+1 \cong$ & -3 \\
\hline 24 & The pharmacy has all the medicines that I need & 0 & -4 & $+1 “$ \\
\hline 25 & In an emergency, I can easily find a pharmacy for pharmaceutical services & $+4^{\pi *}$ & $-1^{\star \pi}$ & $+1^{\pi \pi}$ \\
\hline 26 & I am satisfied with the information provided by the pharmacist & $0^{\pi x}$ & +1 & +1 \\
\hline 27 & The pharmacy area is well-lit and clean & $+3^{n}$ & $-1^{n}$ & $+4 \cong$ \\
\hline 28 & The pharmacist listens attentively to my complaints about my health & 0 & $+5^{n}$ & $-1 “$ \\
\hline 29 & I get information about what to do if I miss a dose & $-4{ }^{n}$ & $-1^{\wedge}$ & $-4 n$ \\
\hline 30 & $\begin{array}{l}\text { The pharmacist helps select the medicines and provides information about } \\
\text { alternative medicines and their prices }\end{array}$ & $-2^{* *}$ & $+3^{* *}$ & $-1^{\star *}$ \\
\hline 31 & The pharmacist is busy and does not allow enough time for consultation & $-1^{\pi *}$ & $-5^{\times \pi}$ & $-3^{\pi \pi}$ \\
\hline 32 & $\begin{array}{l}\text { The pharmacy provides good pharmaceutical services; I would continue to use } \\
\text { these services }\end{array}$ & -1 & 0 & $0^{*}$ \\
\hline 33 & $\begin{array}{l}\text { The pharmacist provides necessary warnings about the side effects and possible } \\
\text { interactions of medicines }\end{array}$ & $-2^{* *}$ & $+4^{* *}$ & $-4^{* *}$ \\
\hline 34 & The number of counters in the pharmacy for dispensing medicines is sufficient & $+1^{\pi *}$ & $-1^{\pi *}$ & $+2^{\pi \times}$ \\
\hline 35 & While communicating with pharmacists, I feel respected and comfortable & $+1{ }^{n}$ & +1 & +2 \\
\hline 36 & Dispensing of the medication by the pharmacist does not take much time & $-3^{n}$ & $-5^{n}$ & $-5^{\wedge}$ \\
\hline 37 & The pharmacist explains what needs to be done to achieve an effective treatment & $-1 \cdots$ & $+4 "$ & -2 \\
\hline 38 & $\begin{array}{l}\text { Before dispensing the medicines, the pharmacist rechecks the medicines' name } \\
\text { and dosage }\end{array}$ & $+2^{*}$ & +3 & +2 \\
\hline 39 & The pharmacist is able to explain things clearly for me to understand & $-2^{n}$ & $+1^{\prime \prime}$ & 0 \\
\hline 40 & $\begin{array}{l}\text { All the efforts of the pharmacist are to help improve my health and not to profit as } \\
\text { much as possible on my account }\end{array}$ & $-5^{\star *}$ & -3 & $-3^{* *}$ \\
\hline
\end{tabular}

${ }^{\star}$ Distinguishing statement with significance of $p<0.05 ;{ }^{\star \star}$ Distinguishing statement with significance of $p<0.01$

\section{Factor 2: Availability of medication consultations}

Factor 2 had eigenvalues of 15.17, which accounts for $11 \%$ of the total variance of the study. This factor had 26 participants who significantly loaded on it. They expressed satisfaction with the information given by the pharmacist about the use of medication not only orally (\#22: +5$)$, but also in writing $(\# 10:+4)$. They received advice on what to do to achieve effective treatment $(\# 37:+4)$, as well as on the side effects and interactions of medicines (\#33: +4). Besides, pharmacists allocated sufficient time for medication consultation (\#31: -5) and helped in recommending medicines by providing information about alternative medicines and their prices (\# 30: +3). Participants were also very satisfied with the pharmacists' attitude toward them such as paying attention to their health concerns (\#28: +5) and being willing to answer any question (\#7: +3$)$. However, they were not satisfied with the private medication consultation settings at the pharmacies (\#17: -4).

\section{Factor 3: Accessibility of medicines}

Factor 3 had eigenvalues of 19.14, which accounts for $13 \%$ of the total variance of the study. This factor had 30 participants who significantly loaded on it. In this factor, customer satisfaction was mainly related to getting a sufficient number of medicines $(\# 16:+5)$ with clear labels (\#2: +5$)$ in the shopping process. In addition, customers had confidence in the quality of medicines (\#9: +3 ) and could clearly view their price information $(\# 15:+4)$. However, they had low satisfaction with the variety of necessary medicines for their needs $(\# 24:+1)$ and the reasonableness of the prices $(\# 4:+2)$ charged by the pharmacies.

\section{DISCUSSION}

This study highlights different patterns of customer opinions toward the quality of community pharmacy services in Vietnam. The three explored patterns were completely independent of one another. There were a large number of distinguishing statements for each viewpoint without any consensus statementsthose that have no significant differences between any pair of factors [30]. The current study does not have many new findings compared to previous studies. However, by exploring the characteristics of the idealized Qsort (see Figure 3) for each factor, it provides a clear picture that reveals a more detailed and insightful view of the subjective opinion of pharmaceutical customers in Vietnam. 


\begin{tabular}{|c|c|c|c|c|c|c|c|c|c|c|}
\hline-5 & -4 & -3 & -2 & -1 & 0 & +1 & +2 & +3 & +4 & +5 \\
\hline $\begin{array}{l}\text { 15. Information on } \\
\text { medicine prices is } \\
\text { clearly visible }\end{array}$ & \begin{tabular}{|l|}
11. The \\
pharmacy has a \\
comfortable \\
waiting area and \\
a sufficient \\
number of seats
\end{tabular} & $\begin{array}{l}\text { 4. The pharmacy } \\
\text { always offers } \\
\text { medicines at an } \\
\text { affordable price }\end{array}$ & $\begin{array}{l}\text { 33. The pharmacist } \\
\text { provides necessary } \\
\text { warnings about the } \\
\text { side effects and } \\
\text { possible } \\
\text { interactions of } \\
\text { medicines }\end{array}$ & $\begin{array}{l}\text { 1. The } \\
\text { pharmacist has } \\
\text { high } \\
\text { professional } \\
\text { knowledge }\end{array}$ & \begin{tabular}{|l|} 
18. If I have \\
health problems, \\
I will go to the \\
pharmacy. After \\
consulting a \\
pharmacist, I feel \\
better \\
\end{tabular} & $\begin{array}{l}\text { 2. The labels of } \\
\text { the medicines I } \\
\text { get are clear and } \\
\text { easy to read }\end{array}$ & $\begin{array}{l}\text { 38. Before } \\
\text { dispensing the } \\
\text { medicines, the } \\
\text { pharmacist } \\
\text { rechecks the } \\
\text { medicines' name } \\
\text { and dosage } \\
\end{array}$ & $\begin{array}{l}\text { 19. The pharmacist } \\
\text { asks me questions } \\
\text { related to the } \\
\text { disease to ensure } \\
\text { that my medicine } \\
\text { use is reasonable }\end{array}$ & $\begin{array}{l}\text { 22. The } \\
\text { pharmacist } \\
\text { indicates how to } \\
\text { take medicines } \\
\text { and provides } \\
\text { advice on their } \\
\text { frequency of use }\end{array}$ & $\begin{array}{l}\text { 14. Pharmacy } \\
\text { services are } \\
\text { easily accessible } \\
\text { and no prior } \\
\text { appointment is } \\
\text { necessary before } \\
\text { a visit } \\
\end{array}$ \\
\hline \multirow[t]{5}{*}{$\begin{array}{l}\text { 40. All the efforts of } \\
\text { the pharmacist are to } \\
\text { help improve } \\
\text { myhealth and not to } \\
\text { profit as much as } \\
\text { possible on my } \\
\text { account } \\
\end{array}$} & $\begin{array}{l}\text { 23. The } \\
\text { pharmacist gives } \\
\text { advice on } \\
\text { maintaining my } \\
\text { health and a } \\
\text { healthy lifestyle }\end{array}$ & $\begin{array}{l}\text { 36. Dispensing of } \\
\text { the medication } \\
\text { by the } \\
\text { pharmacist does } \\
\text { not take much } \\
\text { time }\end{array}$ & $\begin{array}{l}12 . \text { I trust the } \\
\text { pharmacist; he } \\
\text { honors the } \\
\text { confidentiality of } \\
\text { information } \\
\text { regarding me and } \\
\text { my purchases }\end{array}$ & $\begin{array}{l}\text { 9. I trust the } \\
\text { quality of the } \\
\text { medicines } \\
\text { purchased at } \\
\text { the pharmacy }\end{array}$ & \begin{tabular}{|l|} 
10. To prevent \\
mistakes, the \\
pharmacist \\
provides \\
information on \\
medication use in \\
writing
\end{tabular} & \begin{tabular}{|l|} 
35. While \\
communicating \\
with pharmacists, \\
I feel respected \\
and comfortable
\end{tabular} & $\begin{array}{l}\text { 13. After } \\
\text { consultations, I am } \\
\text { well aware of the } \\
\text { rules for taking } \\
\text { medicines }\end{array}$ & $\begin{array}{l}\text { 27. The pharmacy } \\
\text { area is well-lit and } \\
\text { clean }\end{array}$ & $\begin{array}{l}\text { 8. Opening hours } \\
\text { of the pharmacy } \\
\text { are convenient } \\
\text { for me }\end{array}$ & $\begin{array}{l}\text { 20. The } \\
\text { pharmacy is } \\
\text { located in a } \\
\text { convenient } \\
\text { location, close to } \\
\text { my home or } \\
\text { workplace }\end{array}$ \\
\hline & $\begin{array}{l}\text { 29. I get } \\
\text { information about } \\
\text { what to do if I } \\
\text { miss a dose }\end{array}$ & $\begin{array}{l}\text { 6. I get advice } \\
\text { about how to } \\
\text { store } \\
\text { medications at } \\
\text { home from the } \\
\text { pharmacist }\end{array}$ & $\begin{array}{l}\text { 30. The pharmacist } \\
\text { helps select the } \\
\text { medicines and } \\
\text { provides } \\
\text { information } \\
\text { aboutalternative } \\
\text { medicines and their } \\
\text { prices }\end{array}$ & $\begin{array}{l}31 . \text { The } \\
\text { pharmacist is } \\
\text { busy and does } \\
\text { not allow } \\
\text { enough time } \\
\text { for consultation }\end{array}$ & $\begin{array}{l}\text { 24. The } \\
\text { pharmacy has all } \\
\text { the medicines } \\
\text { that I need }\end{array}$ & $\begin{array}{l}\text { 5. Appearance of } \\
\text { the pharmacy is } \\
\text { professional and } \\
\text { aesthetic }\end{array}$ & $\begin{array}{l}\text { 7. The pharmacist } \\
\text { is willing to answer } \\
\text { all of my questions }\end{array}$ & $\begin{array}{l}16 . \text { I get the } \\
\text { required amount of } \\
\text { necessary } \\
\text { medicines }\end{array}$ & $\begin{array}{l}\text { 25. In an } \\
\text { emergency, I can } \\
\text { easily find a } \\
\text { pharmacy for } \\
\text { pharmaceutical } \\
\text { services }\end{array}$ & \\
\hline & & & $\begin{array}{l}\text { 39. The pharmacist } \\
\text { is able to explain } \\
\text { things clearly for } \\
\text { me to understand }\end{array}$ & \begin{tabular}{|l|} 
37. The \\
pharmacist \\
explains what \\
needs to be \\
done to \\
achieve an \\
effective \\
treatment \\
\end{tabular} & \begin{tabular}{l|} 
28. The \\
pharmacist \\
listens attentively \\
to my complaints \\
about my health
\end{tabular} & $\begin{array}{l}\text { 34. The number of } \\
\text { counters in the } \\
\text { pharmacy for } \\
\text { dispensing } \\
\text { medicines is } \\
\text { sufficient }\end{array}$ & $\begin{array}{l}\text { 3. The pharmacist } \\
\text { provides easy-to- } \\
\text { understand } \\
\text { information }\end{array}$ & & & \\
\hline & & & & \begin{tabular}{|l|} 
32. The \\
pharmacy \\
provides good \\
pharmaceutical \\
services; I \\
would continue \\
to use these \\
services \\
\end{tabular} & $\begin{array}{l}\text { 21. The } \\
\text { pharmacist is a } \\
\text { courteous, } \\
\text { friendly, and } \\
\text { helpful person } \\
\end{array}$ & $\begin{array}{l}\text { 17. The pharmacy } \\
\text { does not provide } \\
\text { for private } \\
\text { counseling areas; } \\
\text { other customers } \\
\text { can overhear } \\
\text { conversations or } \\
\text { see the medicines } \\
\end{array}$ & & & & \\
\hline & & & & & $\begin{array}{l}\text { 26. I am satisfied } \\
\text { with the } \\
\text { information } \\
\text { provided by the } \\
\text { pharmacist }\end{array}$ & & & & & \\
\hline
\end{tabular}

Figure 3: An example of an idealized Q-sort for factor 1 
In the context of the market economy in Vietnam, activities related to the supply and distribution of medicines have received attention and attracted participation from many economic stakeholders such as enterprises, pharmacies, and medical facilities not only in the public sectors, but also in the private sectors [31]. This led to the creation of a network of pharmacies that were widely distributed and covered all areas of the country of Vietnam [10]. This is one of the reasons to explain why participants in factor 1 represented the pattern of high satisfaction with access to pharmacies. However, there are still some limitations with regard to the setting of pharmacies such as waiting areas and seating. Another study reported similar results in Ethiopia and showed that patients were satisfied or very satisfied with the pharmacy location (69.3\%) but their satisfaction with the available number of chairs in the waiting area was poor or very poor (50.5\%) [32].

Over a long period of implementation of the "Doi moi" (renovation) policy since the late 1980s [33], the Vietnamese healthcare system has actively improved [34]. Currently, the pharmaceutical sector in Vietnam has achieved remarkable success in national management from the manufacture and distribution of medicines to its effective, safe, and appropriate use [35]. The results of the present research on factors 2 and 3 reflects a significant improvement of current Vietnamese pharmacy services in patient medication counseling as well as regarding the population's access to medicines. However, there are some limitations with regard to the privacy of the patients' medication consultations, as well as the availability of the full range of necessary medicines and the fairness of their prices at community pharmacies, which need to be overcome. Similar findings from a study conducted in the United Arab Emirates showed that pharmacy customer satisfaction with medication prices was at a moderate level [36].

For the first time, a study using Q-methodology was conducted in Vietnam. Moreover, data collection through $\mathrm{Q}$-sort based on a quasinormal distribution grid is a more complex process than traditional questionnaire surveys. Therefore, this collection method required the direct involvement of the researcher and a trained assistant in providing detailed guidance on the Q-sort completion steps to ensure that participants understood and followed them correctly when the study was conducted in Vietnam.
There are some limitations to this study. Only 10 pharmacies from each of the four major cities in Vietnam were selected for the study. Descriptive statistics of frequency distribution for statements in each factor were also not reported in this study because research using Q-methodology does not require it [16]. Furthermore, the extracted factors accounted for a not-too-large $41 \%$ of the total variance. This can be explained by the complexity of data collection tools through Qsorts and the majority of participants with high school education. However, the study's values are within the allowable range; according to Qresearchers, a variance greater than $35 \%$ is considered acceptable for a Q-study [13]. In the future, we hope to expand the number of participants and focus not only on community pharmacies in the big cities but also on those in small cities and rural areas.

\section{CONCLUSION}

This study identifies three patterns of pharmaceutical customers' distinct viewpoints on the quality of community pharmacy services in Vietnam using Q-methodology. The findings of this study contribute to improving the understanding of pharmaceutical policymakers and pharmacy staff about the advantages and disadvantages of current pharmaceutical services, which serves the ultimate goal of the supply of best-quality pharmacy services for the community. Q-methodology is a powerful and useful tool to understand human subjectivity. Based on its successful application to this current research, we hope to motivate many other researchers in the future to apply Q-methodology to understand the subjective views of not only pharmacy customers but also pharmacy staff, managers, and pharmaceutical policymakers.

\section{DECLARATIONS}

\section{Acknowledgement}

The authors are grateful to Heads of Department of Pharmaceutical Management and Economics in Peoples' Friendship University of Russia and proprietors of all the community pharmacies in Vietnam for their cooperation. The study was part of the PharmD dissertation by VDT in the Peoples' Friendship University of Russia, Russia and was funded by the authors.

\section{Conflict of Interest}

No conflict of interest associated with this work. 


\section{Contribution of Authors}

The authors declare that this work was done by the authors named in this article and all liabilities pertaining to claims relating to the content of this article will be borne by them.

\section{REFERENCES}

1. Hindi AMK, Schafheutle El, Jacobs S. Patient and public perspectives of community pharmacies in the United Kingdom: a systematic review. Heal Expect 2018; 21: 409-428.

2. Merks $P$, Świeczkowski D, Jaguszewski MJ. Patients' perception of pharmaceutical services available in a community pharmacy among patients living in a rural area of the United Kingdom. Pharm Pract (Granada) 2016; 14: 774.

3. Steeb $D R$, Joyner $P U$, Thakker DR. Exploring the role of the pharmacist in global health. J Am Pharm Assoc 2014; 54: 552-555.

4. Castillo D, Burgos F, Gascón MP. The role of community pharmacies in respiratory disease control. Arch Bronconeumol 2015; 51: 429-430.

5. Mossialos E, Naci H, Courtin E, Expanding the role of community pharmacists: Policymaking in the absence of policy-relevant evidence? Heal Policy 2013; 111: 135 148.

6. Goel P, Ross-Degnan D, Berman P, Soumerai S. Retail pharmacies in developing countries: $A$ behavior and intervention framework. Soc Sci Med 1996; 42: 11551161.

7. Chowdhury F, Sturm-Ramirez K, Al Mamun A, luliano $A D$, Bhuiyan MU, Chisti MJ, Ahmed M, Haider S, Rahman M, Azziz-Baumgartner E. Factors driving customers to seek health care from pharmacies for acute respiratory illness and treatment recommendations from drug sellers in Dhaka City, Bangladesh. Patient Prefer Adherenc 2017; 11: 479486.

8. Väänänen $M H$, Lyles $A$, Airaksinen $M$. The symptom mitigation path of mobile community residents: Community pharmacy's role. Heal Policy 2009; 89: 14 25.

9. Brata C, Gudka S, Schneider CR, Clifford RM. A review of the provision of appropriate advice by pharmacy staff for self-medication in developing countries. Res Soc Adm Pharm 2015; 11: 136-153.

10. Wang CN, Dang DC, Van Thanh N, Quang PK. A study of customers' behavior in the use of pharmaceutical services - drugstores in the South of Vietnam. Res World Econ 2018; 9: 1-8.

11. Nguyen TA, Vitry A, Roughead EE. Pharmaceutical policy in Vietnam. In: Babar ZUD, editor. Pharmaceutical policy in countries with developing healthcare systems. Cham: Springer International Publishing; 2017; pp 7594.
12. Smith $F$. The quality of private pharmacy services in low and middle-income countries: A systematic review. Pharm World Sci 2009; 31: 351-361.

13. Watts $S$, Stenner P. Doing $Q$ methodological research: Theory, method and interpretation. London: Sage Publications; 2012.

14. Brown SR. Q methodology and qualitative research. Qual Health Res 1996;6:561-567.

15. Brown SR. A primer on $Q$ methodology. Operant Subj 1993; 16: 91-136.

16. Davis $\mathrm{CH}$, Michelle C. $Q$ methodology in audience research: Bridging the qualitative/quantitative 'Divide'? Participations 2011; 8: 559-593.

17. Brown SR. Political subjectivity: Applications of $Q$ methodology in political science. New Haven and London: Yale university press; 1980.

18. Ellingsen IT, Størksen I, Stephens P. Q methodology in social work research. Int J Soc Res Methodol 2010; 13: 395-409.

19. Valenta AL, Wigger U. Q-methodology: Definition and application in health care informatics. J Am Med Inform Assoc 1997; 4: 501-510.

20. Watts $S$, Stenner $P$. Doing $Q$ methodology: Theory, method and interpretation. Qual Res Psychol 2005; 2: 67-91.

21. Rogers RS. Q methodology. In: Smith JA, Harre R, Van Langenhove $L$, editors. Rethinking methods in psychology. London, Thousand Oaks and New Delhi: Sage Publications; 1995.

22. Dziopa F, Ahern K. A systematic literature review of the applications of Q-technique and its methodology. Methodol 2011; 7: 39-55.

23. Schmolck P. PQMethod version 2.35 - a specialized program for doing $Q$ methodology. Available from: http://schmolck.userweb.mwn.de/qmethod/downpqwin.h tm.

24. Kaiser HF. The application of electronic computers to factor analysis. Educ Psychol Meas 1960; 20: 141-151.

25. Guttman L. Some necessary conditions for commonfactor analysis. Psychometrika 1954; 19: 149-161.

26. Cattell RB. The scree test for the number of factors. Multivariate Behav Res 1996; 1: 245-276.

27. Horn JL. A rationale and test for the number of factors in factor analysis. Psychometrika 1965; 30: 179-185.

28. O'connor BP. SPSS and SAS programs for determining the number of components using parallel analysis and Velicer's MAP test. Behav Res Methods Instruments Comput 2000; 32: 396-402.

29. Akhtar-Danesh N, Baumann A, Cordingley L. Qmethodology in nursing research: $A$ promising method for the study of subjectivity. West J Nurs Res 2008; 30 : 759-773.

30. Zabala A, Pascual U. Bootstrapping Q Methodology to Improve the Understanding of Human Perspectives. PLoS One 2016;11: e0148087.

31. Vietnam Ministry of Health. Joint annual health review 2010: Vietnam's health system on the threshold of the 
five-year plan 2011-2015. Hanoi: Vietnam Ministry of Health; 2010.

32. Ayalew MB, Taye $K$, Asfaw $D$, Lemma B, Dadi $F$, Solomon $H$, Tazeze $H$, Tsega B. Patients'/clients' expectation toward and satisfaction from pharmacy services. J Res Pharm Pract 2017; 6: 21-26.

33. Witter $S$. 'Doi moi' and health: The effect of economic reforms on the health system in Vietnam. Int $J$ Health Plann Manage 1996; 11: 159-172.
34. Chuc NT, Tomson G. 'Doi moi' and private pharmacies: a case study on dispensing and financial issues in Hanoi, Vietnam. Eur J Clin Pharmacol 1999; 55: 325-332.

35. Vietnam Ministry of Health. Joint annual health review 2015: Strengthening primary health care at the grassroots towards universal health coverage. Hanoi: Medical Publishing House; 2016.

36. Hasan S, Sulieman H, Stewart K, Chapman CB, Hasan $M Y$, Kong DCM. Assessing patient satisfaction with community pharmacy in the UAE using a newlyvalidated tool. Res Soc Adm Pharm 2013; 9: 841-850. 